\title{
Herbage Production Responses to Pelleted Fenuron and Granular 2,3,6-TBA
}

\author{
EUGENE E. HUGHES AND R. A. DARROW 1 \\ Range Conservationist (Research) Agricultural Research \\ Service, USDA, Los Lunas, New Mexico, and Chief, \\ Crops Division, U. S. Army Biological Laboratories, Fort \\ Detrick, Maryland
}

\section{Introduction}

In an effort to extend the scope of control measures for undesirable plants, granular or pelleted forms of certain herbicides have been developed. These formulations may be applied on the soil surface where they will be carried into the soil by rainfall and enter the plant roots. This type of herbicide may be used on grasses as well as on other plants. Brush control research has been directed toward the use of these new granular or pelleted chemicals, particularly 3-phenyl-1, 1-dimethylurea (fenuron), and 2,3,6-trichlorobenzoic acid (2,3,6-TBA). Little is known of the tolerance of native range grasses to soil herbicides, especially to the higher rates of application.

In an effort to supply information on the effects of these granular herbicides on grasses and the duration of toxicity under varying soil conditions, this study was designed to measure the effects of soil surface applications of fenuron and 2,3,6TBA at different rates and dates of application on native forage production on three range sites.

\section{Review of Literature}

Most of the research in selective control by granular herbicides has dealt with pre-emergence weed and grass control. Carlson (1954) stated that in tests on pre-emergence weed control in sugar cane (Sacchavum officinarum L.), rates up to 5 pounds per acre of 3-chloropheny 1-1, 1-dimethylurea (monuron) did not harm the crop. Cristoph and Fisk (1954) study- ing the stage of growth at which plants were affected, tested monuron on barley (Hordeum vulgare L.) and soybeans (Glycine $\max$ [L.] Merr.) at rates up to 2 pounds per acre. They found that 30 percent of the barley plants treated before early jointing were killed. At 0.75 pound per acre there was some leaf dieback and at 0.25 pound there was no apparent effect. Darrow and McCully (1958), studying the effect of applications of fenuron pellets on post oak (Quercus stellata Wang.) and blackjack oak (Quercus marilandica Muenchh.), found that at 4 pounds of active material per acre desirable perennial grasses apparently were not damaged.

Previous studies with 2,3,6TBA have been conducted principally with foliage spray applications. Work by Furtick, et $\mathrm{al}^{2}$ involved the use of 2,3,6-TBA for post-emergence treatment of grasses. Their results showed that both 1- and 2-pound rates completely controlled tall fescue (Festuca arundinacea Schreb.), ryegrass (Lolium spp.), orchardgrass (Dactylis glomerata L.),

1 This work was carried out by the senior author in 1957 while serving as research assistant at the Texas Agricultural Experiment Station, College Station, Texas, under the co-author, then Professor of Range Management at that location. Work was in partial fulfillment for a master's degree in Range Management at Texas A. \& M. College, College Station, Texas.

2 Technical Service Data Sheet, H-63. March 3, 1956. American Chemical Paint Co.

3 Hooker Electrochemical Co. Progress Report. 1957. and red fescue (Festuca rubra L.). A progress report by Buchholtz presented to the North Central Weed Control Conference in $1956^{3}$ showed that the formulation $\mathrm{X}-80$, a polychlorobenzoic acid, controlled 90 percent of perennial quackgrass (Agropyron repens [L.] Beauv.) at a 4-pound-per-acre rate. Darrow (1957) reported that 2,3,6TBA when applied as an oil spray, at a 2- to 4-pound rate, is about equal to 1.5 pounds of 2,4 , 5 -T or $2-(2,4,5,-\mathrm{TP})$ esters when used for control of oak and associated woody species.

\section{Methods and Materials}

The study area was on the Range and Forestry Area of the Texas Agricultural Experiment Station, approximately 2.5 miles southwest of College Station. The vegetation consisted of post and blackjack oaks with various shrubs and areas of pure grassland interspersed. This study was conducted in such open grassland areas on three range sites: sandy upland, prairie upland, and bottomland, as described by Nord (1953).

The soils are red and yellow podzolic with friable to dense subsoils or claypan soils. The sandy upland soil is a Tabor fine sandy loam and has a topsoil depth of 6 to 10 inches with very slowly permeable subsoil of mottled clay. The dominant grass is little bluestem (Andropogon scoparius Michx.)

The prairie upland soil is Houston-Hunt clay with an 18inch layer of yellowish-brown or gray clay grading downward to an olive or brownish-yellow calcareous clay subsoil which is only slowly permeable. Upon drying, this soil cracks deeply. Texas needlegrass (Stipa leucotricha Trin. \& Rupr.) and sideoats grama (Bouteloua curtipendula [Michx.] Torr.) inhabit this site.

Bottomland soils are Gowen clay loam, derived from transported materials. The type is fri- 
able to firm, very hard when dry, sticky when wet, with the upper 2 feet darkened by humus. The soil exhibits practically no development because of its young age. Brownseed paspalum (Paspalum plicatulum Michx.) is the dominant grass.

Precipitation during the study at Easterwood Airport within a mile of all three sites is shown by 15-day periods in Table 1 .

Hand-broadcast surface applications of $1 / 8$-inch extruded pellets of fenuron and 2,3,6-TBA $8 / 15$ granules were made on three dates, December 15, 1957, February 15, 1959, and April 15,1958 , on each of the three

\section{Table 1. Precipitation from Decem- ber 15, 1957, to June 1, 1958, East- erwood Airport, College Station, Texas.}

\begin{tabular}{|c|c|c|}
\hline Period & $\begin{array}{c}15 \text {-day } \\
\text { total }\end{array}$ & $\begin{array}{c}\text { Accumu- } \\
\text { lated } \\
\text { total }\end{array}$ \\
\hline \multicolumn{3}{|c|}{$-\ldots--$ (Inches) $-\cdots---$} \\
\hline Dec 15-Jan 1 & 2.61 & 2.61 \\
\hline Jan 1-Jan 15 & 1.37 & 3.98 \\
\hline Jan 15 -Feb 1 & 1.68 & 5.66 \\
\hline Feb 1 -Feb 15 & .66 & 6.32 \\
\hline Feb 15-Mar 1 & 2.06 & 8.38 \\
\hline Mar 1-Mar 15 & .40 & 8.78 \\
\hline Mar 15-Apr 1 & 1.18 & 9.96 \\
\hline Apr 1-Apr 15 & .59 & 10.55 \\
\hline Apr 15-May 1 & 3.58 & 14.13 \\
\hline May 1-May 15 & 1.98 & 16.11 \\
\hline May 15-June 1 & .01 & 16.12 \\
\hline
\end{tabular}

range sites. Treatments on each date were fenuron at 4,6 ,8,10 , and $12 \mathrm{lb} / \mathrm{A}$ and 2,3,6-TBA at $6,9,12$, and $15 \mathrm{lb} / \mathrm{A}$ on an active ingredient basis, and none (check).

The experiment consisted of square rod plots in a randomized block design with three blocks on each site. A five-foot buffer zone was left between adjacent plots to minimize the marginal effects of herbicide treatments.

In June, 1958, at the end of the study, herbage was clipped from 8 randomly selected squarefoot subplots in the center $15.5 \times 15.5$ feet of each plot. Samples were oven-dried at $70^{\circ}$ $\mathrm{C}$ for 24 hours and weighed.

\section{Results}

On the sandy upland site herbage production was not greatly affected by application of herbicides (Table 2). No major differences in production attributable to treatment occurred. Although there was some variation in the means of subplots, analysis of variance of treatment means showed no significant differences in the means for months, treatments, or the interaction of month and treatment.

On the prairie upland site 2,3,6-TBA appeared to reduce herbage production more than fenuron. Treatments of 2,3,6TBA at the higher rates in April and February greatly reduced grass yields. Effects of fenuron were not consistent but there was a trend toward reductions from the December to the April applications. These decreases were more pronounced and more consistent than on the other sites. Analysis of variance showed a highly significant difference among months, treatments, and the month-treatment interaction. A significant interaction between month and treatment indicated that the treatments made in one month differed in effect from those in the next (Table 2). All treatments show this interaction.

Applications of 2,3,6-TBA at 9 pounds per acre and higher in February and April definitely lowered herbage production on this site.

On the bottomland site treatments with 2,3,6-TBA caused a significant reduction in herbage production. Fenuron and 2,3,6TBA treatments applied in February and April show a trend toward reduced herbage production when compared to December treatments. Differences were not statistically significant.

Table 2. Herbage production from fenuron and 2,3,6-TB A treated plots clipped on June 1, 1958.

\begin{tabular}{|c|c|c|c|c|c|c|c|c|c|c|c|c|}
\hline \multirow[b]{2}{*}{ Site } & \multirow{2}{*}{$\begin{array}{l}\text { Month of } \\
\text { application }\end{array}$} & \multicolumn{4}{|c|}{ Fenuron (lb/A) } & \multirow[b]{2}{*}{12} & \multicolumn{4}{|c|}{$2,3,6-\mathrm{TBA}(\mathrm{lb} / \mathrm{A})$} & \multirow{2}{*}{$\begin{array}{l}\text { None } \\
\text { (Check) }\end{array}$} & \multirow{2}{*}{$\begin{array}{l}\text { Monthly } \\
\text { means }\end{array}$} \\
\hline & & 4 & 6 & 8 & 10 & & 6 & 9 & 12 & 15 & & \\
\hline & & & & $(1001$ & per & Acre) & & & & & 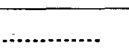 & \\
\hline \multirow[t]{3}{*}{ Sandy Upland } & December & 18 & 13 & 13 & 16 & 13 & 21 & 12 & 9 & 11 & 10 & 14 \\
\hline & February & 15 & 17 & 12 & 20 & 7 & 12 & 11 & 7 & 11 & 10 & 12 \\
\hline & April & 13 & 9 & 16 & 13 & 13 & 12 & 12 & 15 & 10 & 13 & 13 \\
\hline \multicolumn{2}{|c|}{ Treatment means } & 15 & 13 & 14 & 16 & 11 & 15 & 11 & 10 & 11 & 11 & \\
\hline \multirow{3}{*}{ Prairie Upland } & December & 14 & 13 & 14 & 12 & 12 & 14 & 12 & 11 & 9 & 12 & $12 a$ \\
\hline & February & 11 & 11 & 11 & 11 & 11 & 10 & 6 & 7 & 4 & 9 & $9 \mathrm{~b}$ \\
\hline & April & 9 & 10 & 8 & 5 & 10 & 8 & 10 & 4 & 5 & 12 & $8 c$ \\
\hline \multicolumn{2}{|c|}{ Treatment means } & $11 d$ & $11 d$ & $11 d$ & $9 \mathrm{c}$ & $11 d$ & $11 d$ & $9 c$ & $7 \mathrm{~b}$ & $6 a$ & $11 d$ & \\
\hline \multirow[t]{3}{*}{ Bottomland } & December & 12 & 6 & 11 & 7 & 12 & 9 & 7 & 8 & 10 & 10 & 9 \\
\hline & February & 7 & 11 & 7 & 8 & 10 & 7 & 10 & 8 & 8 & 17 & 9 \\
\hline & April & 7 & 9 & 7 & 12 & 3 & 8 & 9 & 6 & 6 & 15 & 8 \\
\hline \multicolumn{2}{|c|}{ Treatment means } & $9 \mathrm{~b}$ & $9 \mathrm{~b}$ & $9 b$ & $9 \mathrm{~b}$ & $8 a b$ & $8 \mathrm{ab}$ & $8 \mathrm{ab}$ & $7 a$ & $8 \mathrm{ab}$ & $14 b$ & \\
\hline
\end{tabular}




\section{Discussion}

Differences in reduction of herbage production from application of herbicides on the three range sites are probably due to soil differences and/or possibly to a differential response of species. This effect could have been due to leaching of the chemical below the root zone before spring growth began. The sandy upland and bottomland sites have lighter soils (sandy and clay loam), while the prairie upland site has a clay soil. Darrow, et al (1959) reported that tests with fenuron on tree species growing on calcareous and heavy-textured soils have been relatively ineffective, but those on sandy and medium-textured soils gave promising results. This would indicate that fenuron moves down readily in lighttextured soils but does not on heavy soils. Persistence of the herbicides in the clay soil could have been a factor.

Reductions in yield at the various sites may be related to the time elapsing between treatment and when the grasses make their growth - warm or cool-season species. Significant reductions in yield were not noted on the sandy upland site (characterized by little bluestem, a warm-season species) and bottomland site (characterized by brownseed paspalum, also warm-season), while highly significant reductions were noted on the prairie upland site from February and April applications. The prairie upland site is characterized by Texas needlegrass, a cool-season grass. This grass was green and growing at the time of the February and April applications, whereas grasses on the other sites were just beginning to grow in April. This could have resulted in greater absorption of herbicide by grasses on the prairie upland and consequently a reduction in production. Also, possibly the Texas needlegrass is more susceptible to these herbicides.

\section{Summary and Conclusions}

Two herbicides, pelleted fenuron and granular 2,3,6-TBA, were hand-broadcast on prairie upland, shallow upland, and bottomland sites to evaluate yield responses of native grasses.

Neither herbicide affected herbage production on the sandy upland site. However, heavy rates of 2,3,6-TBA decreased production on both prairie upland and bottomland sites characterized by clay or clay-loam soils. A greater reduction resulted on the prairie upland site having a coolseason grass, Texas needlegrass, Fenuron also showed a trend to- ward reduced yields of the bottomland site.

No date of application reduced herbage application significantly on the sandy upland site, but there was a highly significant effect on the prairie upland site. February and April applications produced greater reductions than the December applications. The later applications also tended to give lower yields on the bottomland site.

\section{LITERATURE CITED}

Carlson, A. E. 1954. Applications of substituted urea herbicides. Agr. Chem. 9(6) : 44-45, 155-157.

Cristoph, Roy J. and Emma L. Fisk. 1954. Responses of plants to the herbicide CMU. Bot. Gaz. 116:1-14.

DARRow, R. A. 1957. Trichlorobenzoic acid and associated herbicides in the control of weedy plants in Texas. Proc. 10th Southern Weed Conference, pp. 132-138.

Darrow, R. A. and W. C. McCully. 1958. Pellet applications of fenuron for the control of post and blackjack oaks. Texas Agr. Exp. Sta. P.R. 2041. 4 pp.

Darrow, R. A., W. C. McCully aND E. E. Hughes. 1959. Woody plant and grass responses to granular applications of fenuron and chlorinated benzoic acids. Proc. 12th annual Southern Weed Conference.

Nord, E. C. 1953. A study of the Range and Forestry Experimental Area for the purpose of developing a range management plan based on condition classes by site. Unpubl. M. S. thesis. Agr. \& Mech. College of Texas, College Station, Texas.

\title{
Range Management Definitions
}

\author{
By JACOB KATSIR \\ Visiting Student from Israel to Utah State University, 1960
}

Range Management-The art and science of being almost bankrupt, but never passing this point.

Research-The search for truth, but only the truth which you have found before starting the experiment.

SCS Cooperative Agreement-The agency will do what the farmer wants and the farmer will do as he pleases.

BLM Range Condition Formula-The quantity of the vegetation multiplied by the quality divided by the erodability and compaction of the soil will give range condition.

Forest Service Multiple Use-The three main uses of forests are: timber production, timber production, and timber production. 